\title{
The fynbos and the frogs
}

Mark Simmonds

The fynbos of the South African Cape is renowned for its high number of endemic plants and animals, many of which are under threat. Much effort and money are being spent to secure their future. Amphibians may be especially vulnerable due to land drainage, and amongst those facing this and other threats is the Cape clawed toad Xenopus gilli for which a conservation programme has been developed.

At the southernmost tip of the African continent are the Cape Fold mountains and their associated coastal platform. This is the region of the fynbos, a unique vegetation type, which forms much of the Cape Floral Kingdom (Taylor, 1978). Recently this area received publicity when a nature reserve was taken over by the South African Government to be used as a missile testing site (Anon., 1984a). Despite this interest, the richness and diversity of the fynbos and the many threats to its future seem little appreciated.

The Cape Floral Kingdom is one of the six floral kingdoms of the world (Takhtajan, 1969; Good, 1974). It is estimated that it covers only 0.04 per cent of the Earth's land surface; by contrast the Boreal Kingdom covers most of Europe, Asia and all of North America. At the Cape are believed to be some 1000 genera of flowering plants of which 20 per cent are endemic (Goldblatt, 1978). From the Cape Peninsula alone 2400 species are recorded (Adamson and Salter, 1950), which is close to twice the number given for the whole of the British Isles. Heathers and proteas and the families Restionaceae, Iridaceae, Compositae, Leguminosae and Thymelaceae form much of the fynbos (Good, 1974). It is characteristically low and shrubby, with few trees, many tough 104 small-leaved and resinous bushes, succulents and tussock-forming plants. Numerous flowering species treasured in the West have their origins in the fynbos.

The Cape is also noted as an area of endemism of both invertebrates (Stuckenberg, 1962) and lower vertebrates (Bigalke, 1979), but exactly why such a high number of plant and animal species is peculiar to the area is the subject of much debate (Taylor, 1978). Whatever the reasons, there can be no doubt about the present uniqueness of the area. This tip of the continent, however, is densely populated and undergoing a steady population increase. Thus, there is demand for land to build on, to farm and for the construction of reservoirs.

In addition are the problems caused by the introduction of many foreign species to the Cape. Early colonisers brought with them plants both for decoration and to bind the sands of the Cape Flats and make way for development. European conifers were planted for timber and still cover large areas. On the sides of Table Mountain, now a nature reserve, the fallen trees of a past plantation can be seen. These have been 'ringed' (the bark removed in a band near their bases) and left to die as part of a control scheme. Many foreign species are less easily dealt with, however, and successfully invade the fynbos. To illustrate the scale of the problem, the Department of Forestry spent the equivalent of $£ 100,000$ on exotic plant eradication in 1976/77 (Neser and Wells, 1978). Outside of forestry managed land, however, are sites where foreign plants, in particular Acacia spp. and Hakea spp., dominate.

Of the 26 important species of plant invader 18 Oryx Vol 19 No 2 


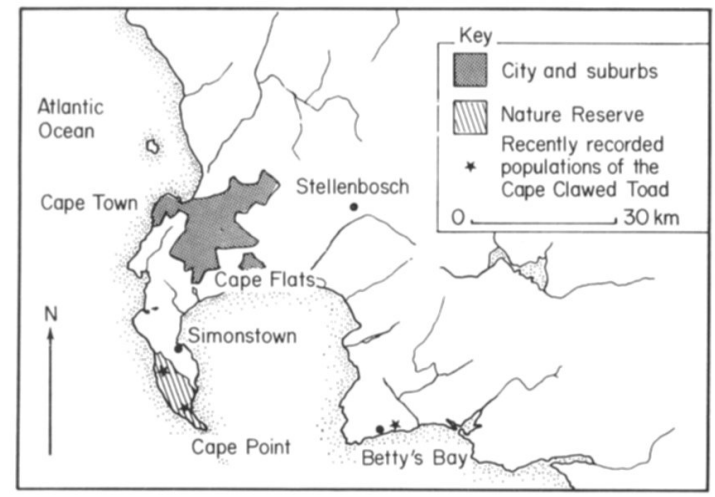

Western Cape Province and the Cape Peninsula.

come from South America and Australia, which have ecological similarities to South Africa (Shaughnessy et al., 1978). The plants are typically fast growing and form dense thickets, excluding the native growth. Usually the invaders have both remarkable regenerative abilities and great reproductive capacity. The Port Jackson Acacia saligna is an example of a successful invader (Boucher and Stirton, 1978). Originally introduced to bind the sandy substratum of the Flats and for the production of tannins used in industry, it now occurs in patches throughout much of the sandy coastal areas. Native of southwestern Australia, it coppices readily after felling or burning.

The reaction of invaders to fire is important; the fynbos is a fire subclimax community and fire is essential to seed release, germination, growth and regeneration in many species. Controlled fires are practised in managed areas, but the desirable frequency is unknown and accidental fires are common during the dry summer months.

The Cape also hosts other foreign species. Amongst these are: game fish, introduced to many rivers to provide sport; the North American grey squirrel, popular with the public because of its tameness, is apparently confined to city parks and conifer plantations; the Himalayan tahr, a kind of mountain goat, is found only on the top of Table Mountain where its numbers are now carefully controlled; and feral cats, dogs, rats, English house sparrows and cockroaches. The introduction and possible spread of these opportunists may adversely affect native species.

The fynbos and the frogs
Other problems affecting the natural environment are caused by human population increase. Much of the Republic's land surface is already used for agriculture and in parts of the Cape the fynbos survives only on mountain slopes surrounded by vast cereal fields. Most of the Cape Flats are covered by the single-storey suburbs of Cape Town and holiday homes are popular along the spectacular coast. While demands for recreational facilities threaten some areas of fynbos, the Western Cape Water Scheme operates to fulfil an essential need. This programme of reservoir construction inevitably destroys much countryside.

Conservation and the countryside are not, however, without their supporters, both governmental and voluntary. There are, for example, three organisations based at the University of Cape Town to monitor threats to the fynbos: the Fynbos Biome Working Group, the Co-ordinating Council for Nature Conservation in the Cape, and the Rare and Endangered Species Survey Team. The Forestry Department, Department of Nature and Environmental Conservation and the National Parks Board have all established nature reserves. Local authorities also manage reserves and the Divisional Council of the Cape administers the largest, the Cape Point Reserve at the tip of the peninsula. Within the 7700 ha of reserve a well equipped team of rangers and labourers care for herds of bontebok, eland, Harteman's mountain zebra and other game. The animals attract the public, but the real value of the reserve is

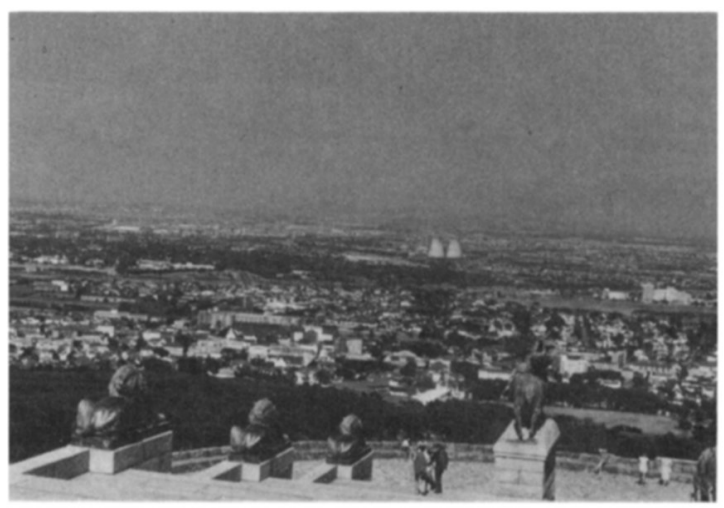

A view of the Cape Flats from the Rhodes Memorial on the side of Table Mountain (M. Simmonds).

105 
usually considered to be in the mountain fynbos itself. Here too are patches of foreign plant growth, but the rangers run a control programme to prevent further spread, slowly destroying established plants and their long-lived seeds and hardy seedlings.

The Cape Point Reserve is also the site of much recent concern over a denizen of the fynbos. Listed in the IUCN Amphibia/Reptilia Red Data Book (Anon., 1975) as vulnerable, the Cape clawed toad Xenopus gilli is almost wholly aquatic with a striped back, speckled ventral surface, flattened pear-shaped body with huge backlegs and large well-webbed feet. The related South African clawed toad, $X$. laevis, is well known throughout the world because of its use in biology classes and, in the past, its use in pregnancy testing. Like X. gilli it occurs at the Cape and from there it is exported all around the world in great numbers. The Cape and South African clawed toads are usually easily distinguished from one another by the distinct pattern and smaller size of the former. $X$. gilli has long been known to be rare and it has been suggested (Rose, 1962) that the 'stronger, more cannibalistic' South African clawed toad was displacing it. Recently the status of the rarer species has been investigated (Simmonds, in prep.) and its distribution found to be restricted to a few small populations and apparently always in close contact with $X$. laevis. The best known and most studied populations are within the Cape Point Reserve. Kobel et al. (1981) have shown that the two species hybridise (the resulting male offspring are infertile, but the females produce viable eggs) and this further complicates the situation as hybrid eggs may be fertilised by either species. Such backcrossing would obviously dilute the genetic integrity of $X$. gilli (see Kobel et al., 1981). If it proved necessary in a conservation attempt to remove both South African clawed toads and hybrids from an area, as seems likely, the identification of species might prove difficult after generations of interbreeding.

Xenopus laevis occurs over much of Africa and seems tolerant of, and is possibly favoured by, human interference with water systems in the Cape, such as raising $\mathrm{pH}$ and increasing the permanence of ponds and ditches (see Loveridge, 1980). The South African clawed toad's opportunistic character and colonising ability, 106

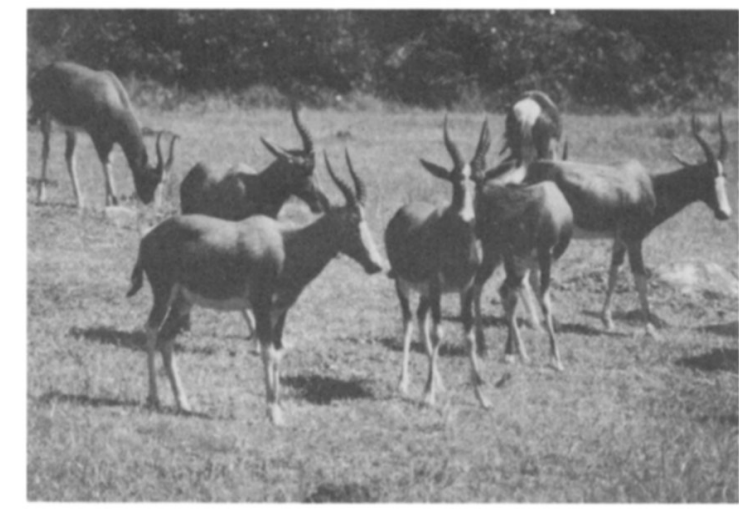

A small herd of the rare bontebok in Cape Point Reserve ( $M$. Simmonds).

which have allowed it to establish feral populations in Europe and America (Simmonds, 1982), combined with its superiority in numbers, and the fact that it hybridises with $X$. gilli would seem to lead inevitably to the disappearance of the Cape clawed toad. This threat has been recognised, however, and interested scientists, both from South Africa and elsewhere, have formed a committee to develop a conservation programme. The animal is difficult to breed in captivity, but there is an established breeding colony in London.

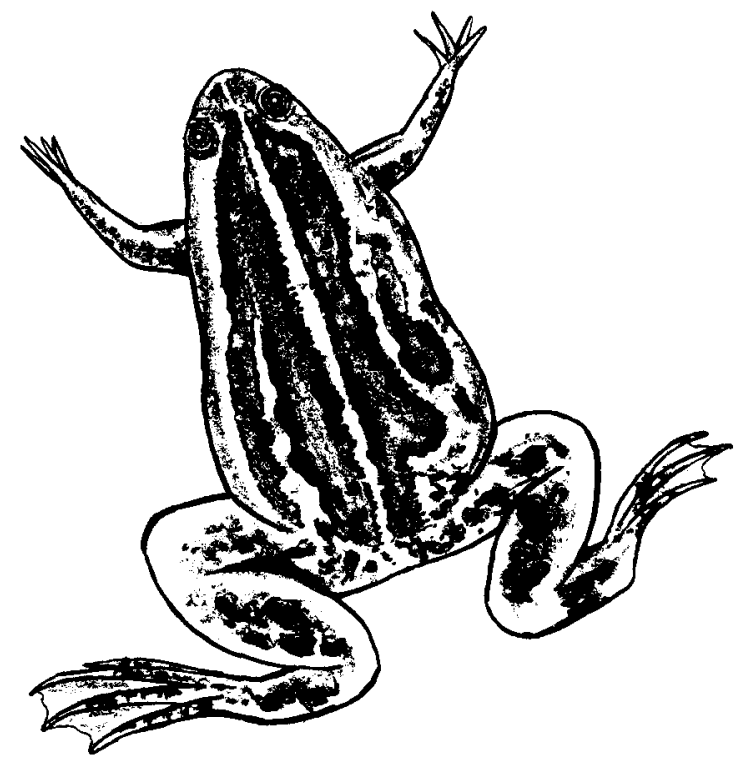

The Cape clawed toad Xenopus gilli (M. Simmonds).

Oryx Vol 19 No 2 
Right: One of the ponds inhabited by clawed toads in Cape Point Reserve ( $M$. Simmonds).

Below: South African clawed toad/Cape clawed toad hybrids found in Cape Point Reserve (M. Simmonds).

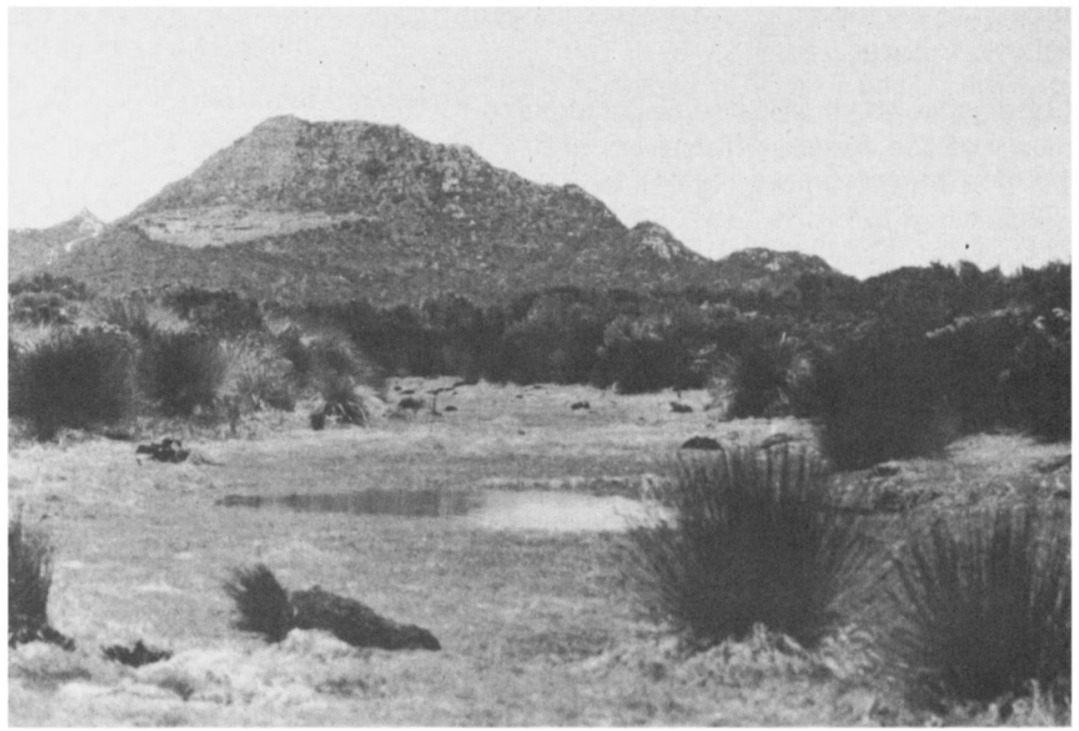

Xenopus spend almost their entire lives in water, surviving dry periods by aestivating in mud at the bottom of ponds, they occasionally cross land and will migrate from one pond to another. This will make eradication difficult, but if the rangers use the same patience they employ in weeding out foreign plants they should eventually succeed. A special pond is to be built at Cape Point,

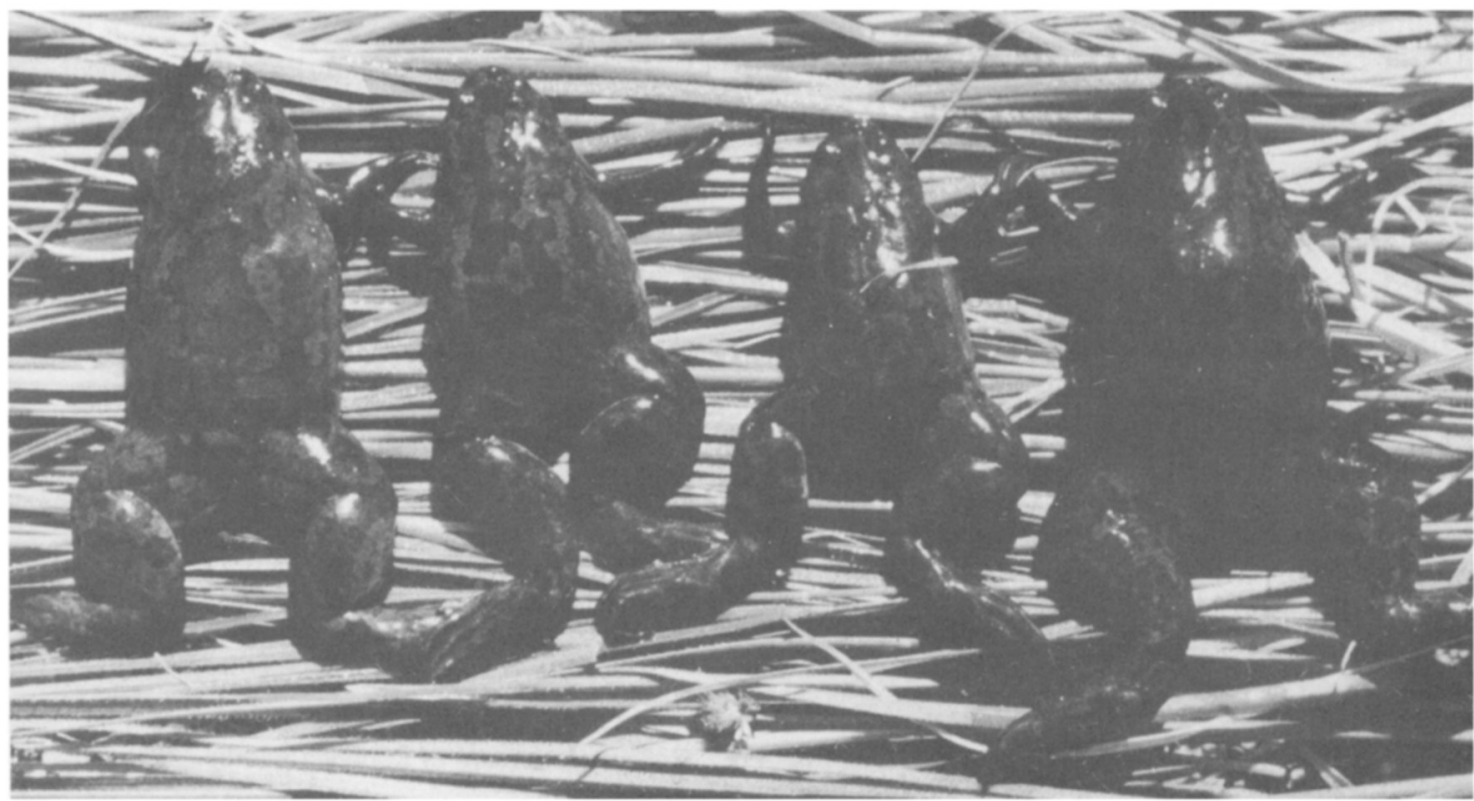


fenced to exclude the unwanted species and carefully monitored.

Other species of frog are also restricted to small areas of the fynbos (Passmore and Carruthers, 1979). The thumbed ghost frog Heleophryne rosei is only found on the slopes of Table Mountain. Its tadpoles may be seen in fastmoving streams, clinging to rocks with their sucker mouths. Adult ghost frogs are, however, rarely observed. Microfrogs Microbatrachella capensis, whose adults are only $1.5 \mathrm{~cm}$ in length, are also only found in the south-western Cape. The drainage of marshland in the region of Betty's Bay is likely to destroy both their habitat (De Villiers, pers. comm.) and that of X. gilli. Much of the fynbos becomes marsh in the winter and similar drainage programmes will be necessary before building can proceed in many areas. Amphibians are thus particularly threatened and, other than those already mentioned, at least three species of rain frog Breviceps spp., the Cape caco Cacostemum namaquense and the banded stream frog Rana montana only occur locally (Passmore and Carruthers, 1979). Many more widely distributed species of frog are also found in the area.

The geometric tortoise Psammobates geometricus is another small rare vertebrate peculiar to the region. Previously restricted to two small areas threatened by the expansion of farming interests 90 per cent of the population was destroyed by fires in the 1983 summer (Anon., 1984b). The habitat will recover if left alone, but with the remaining few animals on private land their future is very much in doubt. This emphasises the vulnerability of those animals of the fynbos with limited distributions.

It has not been possible in this short article to describe the variety of life present in the fynbos, but only to hint at its richness. Perhaps, however, the co-operation of national and international bodies in conservation of the Cape clawed toad, may be indicative of a more general world-wide awareness of threats to the fynbos, and the smallest and probably most vulnerable of the world's floral kingdoms.

\section{Acknowledgment}

I am very grateful to the Winston Churchill Memorial Trust for 108 a fellowship which allowed me to travel to and in South Africa and investigate the fynbos and its inhabitants.

\section{References}

Adamson, R.S. and Salter, T.M. 1950. Flora of the Cape Peninsula. Juta, Cape Town.

Anon. 1975. Red Data Book. Amphibians and Reptiles. IUCN, Morges.

Anon. 1984a. Oryx, 18, 3.

Anon. 1984b. Oryx, 18, 108.

Bigalke, R.C. 1979. Aspects of vertebrate life in fynbos, South Africa. In Ecosystems of the World, 9, 81-95 (Ed. R.L. Specht). Elsevier, Amsterdam.

Boucher, C. and Stirton, C.H. 1978. Port Jackson. In Plant Invaders Beautiful but Dangerous, pp. 60-63 (Ed. C.H. Stirton). Department of Nature and Environmental Conservation of the Cape, Provincial Administration, Cape Town.

Goldblatt, P. 1978. An analysis of the flora of Southern Africa: its characteristics, relationships and origins. Ann. Mo. bot. Gdn. 65, 369-436.

Good, R. 1974. The Geography of the Flowering Plants. Longman, London.

Kobel, H.R., Du Pasquier, L. and Tinsley, R.C. 1981. Natural hybridisation and gene introgression between Xenopus gilli and Xenopus laevis laevis (Anura: Pipidae). J. Zool., Lond. 194, 317-322.

Loveridge, J.P. 1980. The habitat requirements of Xenopus gilli in the Cape Point nature reserve. Progress report: 1 August to 29 February 1980. In Research Report Herpetology. Department of Nature and Environmental Conservation, Cape Town.

Neser, S. and Wells, M.J. 1978. Control of plant invaders. In Plant Invaders Beautiful but Dangerous, pp. 144-153 (Ed. C.H. Stirton). Department of Nature and Environmental Conservation of the Cape, Provincial Administration, Cape Town.

Passmore, N. and Carruthers, V.C. 1979. South African Frogs. Witwatersrand University Press, Johannesberg.

Rose, W, 1962. The Reptiles and Amphibians of Southern Africa. Maskew Miller, Cape Town.

Shaughnessy, G.L., Millar, J.C.G. and Jacot Guillarmod, A.J. 1978. Where did plant invaders come from? In Plant Invaders Beautiful but Dangerous, pp. 144-153 (Ed. C.H Stirton). Department of Nature and Environmental Conservation of the Cape, Provincial Administration, Cape Town.

Simmonds, M.P. 1982. The amphibian invader. World Wildlife News. Winter 1982/83, 6-7.

Simmonds, M.P. (In prep.) Interactions between Xenopus in Southwestern Cape Province.

Stuckenberg, B.R. 1962. The distribution of the montane paleogenic elements in the South African fauna. Annls Cape prov. Mus. 2, 190-205.

Takhtajan, A. 1969. Flowering Plants, Origin and Dispersal Smithsonian Institution Press, Washington DC.

Taylor, H.C. 1978. 'Capensis'. In Biogeography and Ecology of Southern Africa (Ed. M.J.A. Werger) W. Junk, The Hague.

Mark P. Simmonds, Biological Sciences, Queen Mary College, University of London, Mile End Road, London E1 $4 N S$, UK. 